\title{
COMPORTAMENTO ELÉTRICO DE ARENITOS DA FORMAÇÃO MARACANGALHA OBSERVADO EM TESTEMUNHOS E AFLORAMENTOS DA ILHA DOS FRADES, BAHIA
}

\author{
Joelson da Conceição Batista \\ Orientador: Dr. Olivar Antônio Lima de Lima (UFBA) \\ 60 p. - Dissertação (Mestrado) - Defesa 26.06.2007
}

RESUMO. 0 presente trabalho é parte de um projeto de cooperação que busca definir a arquitetura estratigráfica, geometria e heterogeneidades dos reservatórios da Formação Maracangalha, bacia do Recôncavo, Bahia, Brasil. 0 comportamento elétrico, em escala laboratorial, dos testemunhos coletados em afloramentos desta formação na Ilha dos Frades, foi obtido usando medidas elétricas efetuadas nas amostras saturadas com soluções de $\mathrm{NaCl}$ de várias salinidades. Esses dados petrofísicos foram comparados a medidas elétricas realizadas nesses afloramentos ao longo de perfis verticais. Desta forma, a caracterização das heterogeneidades petrofísicas nos corpos rochosos dessa formação teve por base medidas elétricas de afloramentos, associadas na amostragem bem definida para a análise petrofísica das principais fácies definidas, buscando-se entre outras coisas: (1) documentar a variabilidade lateral dos atributos permo-porosos, (2) identificar as variáveis que controlam o desenvolvimento das heterogeneidades macroscópicas que influenciam na qualidade desses reservatórios. A primeira etapa envolveu a realização das medidas elétricas de campo e a coleta de amostras representativas dos afloramentos e em seguida 0 tratamento e interpretação qualitativa dos perfis elétricos adquiridos. A etapa seguinte compreendeu a pesquisa laboratorial envolvendo, testes de calibração dos instrumentos utilizados, e a adaptação e montagem de um portaamostra apropriado para efetuar, com agilidade e confiança, medições elétricas de resistividade e cargabilidade aparente no domínio do tempo. Neste ponto foram realizados a limpeza e o redimensionamento de 22 amostras, seguido do tratamento dos dados laboratoriais e de campo adquiridos. Das medidas elétricas de campo, construímos perfis de resistividade e cargabilidade aparente, os quais foram utilizados para descrever as variabilidades litológicas nos afloramentos perfilados. No tratamento das medidas elétricas de laboratório utilizamos as expressões analíticas desenvolvidas na teoria petrofísica Lima et al. (2005). 0 ajuste as equações aos dados experimentais, obtidos pelo método de múltiplas salinidades, permitiu a diferenciação das amostras quanto à distribuição do tamanho dos grãos e à presença de argilo-minerais ou material condutor, além de uma estimativa quantitativa de seus parâmetros hidráulicos.

ABSTRACT. This work is part of a cooperative research that is trying to define the stratigraphic architecture, the geometry and the heterogeneities of reservoirs within the Maracangalha Formation, Recôncavo basin, Bahia, Brazil. The electrical behavior, in lab scale, of drill cores collected in outcrops of this formation in the Frades Island, was obtained using electrical measurements performed in the samples saturated with solutions of NaCl for six different salinities. These petrophysical data have been compared to electric measurements made at these outcrops in vertical profilings. In this way the petrophysical characterization of these rock bodies were based on electrical measurements in outcrops and samples of this formation, searching for, among others things: (1) the documentation of the lateral variability of their permo-porous attributes, (2) to identify the variables that control the development of macroscopic heterogeneities, influencing the quality of these reservoirs. The first stage included the field work of electrical measurements and the collection of representative samples at outcrops following of field data treatment. The next stage was the laboratorial work involving calibration tests of the used instruments, and the adaptation and assembly of a sample holder appropriated to perform the electrical measurements of resistivity and apparent chargeability, in time domain, with ability and confidence. In this stage we performed the treatment of 22 samples, including cleanning and resizing of the samples, followed by data acquisition in laboratory. From the outcrops measurements, we construct resistivity and IP profiles, that have been used to describe the lithological variabilities in the outcrops. For processing the lab electrical measurements we use the analytical expressions developed in the petrophysical theory described by Lima et al. (2005). The fitting of the multiple salinity experimental data to these equations allowed to group the sample according to the grain size distribution, content of clay minerals besides a quantitative estimation of their hydraulic parameters. 